\title{
Buffalo mozzarella chemical composition and authenticity assessment by electrophoretic profiling
}

\section{Avaliação da composição química e autenticidade de muçarela de búfala por meio do perfil eletroforético}

\author{
Ben-Hur Ramos Ferreira Gonçalves ${ }^{1}$; Grazielly de Jesus Silva ${ }^{1}$; Daniele Gomes \\ Conceição ${ }^{1}$; Antonio Silvio do Egito ${ }^{2}$; Sibelli Passini Barbosa Ferrão ${ }^{3 *}$
}

\begin{abstract}
Buffalo milk mozzarella is often adulterated by the addition of cow's milk. The aim of this study was to assess the quality of buffalo milk mozzarella by using electrophoresis (SDS-PAGE) to detect the addition of cow's milk. Reference cheeses were produced exclusively from combinations of buffalo and cow milk, and labeled reference treatment buffalo or cow (RTB and RTC, respectively). Standardized cheeses were made by combining buffalo milk and $2.5 \%, 5.0 \%, 10 \%, 20 \%, 30 \%, 40 \%$ or $50 \%$ cow's milk. A total of 9 cheese formulations were produced and either frozen immediately (time 0 ) or after 20 days (time 20). Eighteen commercial samples of buffalo mozzarella were sampled between 0-20 days of production. The chemical composition (moisture, ash, fat in dry matter, protein, total solids and defatted dry extract) and physicochemical characteristics (acidity) of the cheeses were evaluated. Proteins and water-soluble peptides (WSP) extracted from RTB, RTC and from the commercial samples, and were analyzed by SDS-PAGE electrophoresis under denaturing conditions. It was not possible to detect the inclusion of cow's milk by the cheeses' chemical and physicochemical properties. However, the separation and detection of peptide and protein fractions of the cheese was possible by electrophoresis. The results of the electrophoretic analysis suggest that $28 \%$ of the commercial samples considered here had evidence of the addition of cow's milk. The methodology described here is important to identify occurrences of fraud in buffalo mozzarella production.
\end{abstract}

Key words: Adulteration. Peptides. Proteins. Cheese. SDS-PAGE.

\section{Resumo}

Objetivou-se com o presente estudo detectar fraudes por adição de leite de vaca em muçarela de búfala. Foram produzidos queijos exclusivamente com leite de búfala (TRB) e vaca (TRV) e com inclusões crescentes de leite bovino ao bubalino $(2,5 \%, 5,0 \%, 10 \%, 20 \%, 30 \%, 40 \%$ e $50 \%)$, totalizando 9 formulações que foram congeladas no dia de fabricação (Tempo 0) e com 20 dias após a data de fabricação (Tempo 20). Foram coletadas 18 amostras comerciais de muçarela de búfala com até 20 dias de fabricação sendo congeladas no Tempo 20. Os queijos foram avaliados em relação à composição química (umidade, cinzas, gordura no extrato seco, proteínas, extrato seco total e extrato seco desengordurado) e característica físico-química (acidez titulável). Proteínas dos queijos muçarela produzidos e amostras comerciais e peptídeos solúveis em água (PSA) extraídos de TRB, TRV e amostras comerciais foram analisados por eletroforese sob condições desnaturantes por meio de dodecil sulfato de sódio (SDS-

\footnotetext{
${ }^{1}$ Discentes, Universidade Estadual do Sudoeste da Bahia, UESB, Itapetinga, BA, Brasil. E-mail: ben_hur_ramos@hotmail.com; grazielly_silva@hotmail.com; danielegomesc@gmail.com

${ }^{2}$ Pesquisador, Empresa Brasileira de Pesquisa Agropecuária, EMBRAPA, Sobral, CE, Brasil. E-mail: silvioegitovasconcelos@, gmail.com

3 Prof ${ }^{\text {a }}$, UESB, Itapetinga, BA, Brasil. E-mail: sibpass@yahoo.com.br

* Author for correspondence
} 
PAGE). Não foi possível detectar adulterações por meio dos resultados de composição química e caracterização físico-química. A técnica SDS-PAGE mostrou-se eficiente na separação e detecção das frações proteicas e peptídeos dos queijos. Em 28\% das amostras comerciais de muçarela de búfala houve indícios de adulteração por adição de leite de vaca. Os resultados deste trabalho mostraram-se importantes para alertar sobre a ocorrência de fraudes em muçarela de búfala.

Palavras-chave: Adulteração. Peptídeos. Proteínas. Queijo. SDS-PAGE.

\section{Introduction}

Studying the quality of food has become more common worldwide in order to verify the authenticity and quality of commercially available products for economic and ethical reasons for the consumer.

In Brazil, "Mozzarella", "Muzzarella" or "Muçarela", is a cheese created from strings of acidified curd. The curd is an intermediary product, which is obtained by milk coagulation with rennet and/or other proper coagulating enzymes, either with or without the action of specific lactic bacteria (BRASIL, 1997).

Buffalo milk is seasonally available, which reduces its production in dairies during some parts of the year (CZERWENKA et al., 2010). To make up for this shortage and the high cost of buffalo milk, some breeders and dairy industries mix buffalo milk with milk from other species, especially cow milk (LÓPEZ-CALLEJA et al., 2005).

Cow and/or buffalo milk can be used for the production of mozzarella, as long as the information is displayed on the product's packaging. Because of this, assessing the quality and species of the milk used to produce the cheese is very important, especially in the case of cheese claiming to be of buffalo origin.

The chemical composition and production of milk by buffalo is influenced by many factors, such as the breed, lactation status, age, handling, feeding, and health of the animals, as well as weather conditions, and the time of year (CZERWENKA et al., 2010).

A number of protein-based methods have been developed to detect the addition of milk from different species (ENNE et al., 2005), including HPLC/MS-MS (RUSSO et al., 2012) and real-time PCR (FELIGINI et al., 2005; LOPPARELLI et al., 2007). Among these methods, electrophoresis is noteworthy for its satisfactory results (GUERREIRO et al., 2013), and inexpensive technology. A common electrophoresis technique makes use of polyacrylamide gel (polyacrylamide gel electrophoresis, PAGE), and can be used in the presence of the surfactant sodium dodecyl sulfate (SDS) (EGITO et al., 2006).

A limitation when analyzing protein fractions by this technique is that the protein profile of the milk of some species is very similar. For this reason, the evaluation of water-soluble peptides (WSP) extracted from the samples is necessary to distinguish these species.

The aim of this study was to detect fraudulent addition of bovine milk to buffalo mozzarella, using SDS-PAGE of total protein and peptides derived from buffalo and bovine milk. Mozzarella produced with different formulations was compared to commercial buffalo mozzarella, and the chemical composition and physicochemical features of the cheeses were determined.

\section{Material and Methods}

\section{Mozzarella cheese production}

The mozzarella cheese was produced in a dairy, from May to December of 2014. Standardized cheeses were made with increasing amounts of cow's milk included in the buffalo milk $(2.5 \%$, $5.0 \%, 10 \%, 20 \%, 30 \%, 40 \%$ e $50 \%$ ), and reference cheeses were also made, either exclusively with cow's milk (RTC) or with buffalo's milk (RTB). 
The total volume of milk used for each formulation was $50 \mathrm{~L}$, with standardization of the fat content to $3.6 \%$ performed after the mixing of the milk, using a mechanical skimmer (GR, Goiânia, GO, Brazil). After pasteurization $\left(65{ }^{\circ} \mathrm{C} \pm 2{ }^{\circ} \mathrm{C} / 30\right.$ min), the milk was cooled $\left(40{ }^{\circ} \mathrm{C} \pm 1{ }^{\circ} \mathrm{C}\right)$ before the addition of $1.0 \mathrm{~g}$ of a freeze-dried mesophilic lactic culture (DVS-R704 Chr Hansen, Boge Allé, DK, Denmark) containing the species Lactococcus lactis subspecies cremoris and Lactococcus lactis subspecies lactis. Once the mixture had reached 35 ${ }^{\circ} \mathrm{C} \pm 1{ }^{\circ} \mathrm{C}, 10.0 \mathrm{~mL}$ of $50 \%$ (w/v) calcium chloride (Coalhopar, Coalhos Bio Paraná LTDA, Alto Piquiri, PR, Brazil) and $20.0 \mathrm{~mL}$ of rennet (liquid coagulant HA-LA ${ }^{\circledR}$, Brazil - Chr Hansen - strength 1:3,000) were added. After the mixture had coagulated (around 20 minutes), the mass was cut into cubes of approximately $1.0 \mathrm{~cm}^{3}$ and stirred for 30 minutes until a cooked and firm curd was obtained. The curd was desorbed, fermented for a period of 18 hours at $25{ }^{\circ} \mathrm{C} \pm 3{ }^{\circ} \mathrm{C}$, sliced, and submitted to a stringing process in water at $80^{\circ} \mathrm{C} \pm 3{ }^{\circ} \mathrm{C}$, before conditioning in proper molds. The cheeses were then salted in brine containing $20 \% \mathrm{NaCl}(\mathrm{w} / \mathrm{v})$ for 60 minutes, followed by drying at $6{ }^{\circ} \mathrm{C} \pm 2{ }^{\circ} \mathrm{C}$ for 12 hours, then vacuum packed (BS 320, R. Baião, Vila Casal Ubá, MG, Brazil). Each milk combination formulation was used to produce cheese in triplicate, with a total of 27 cheeses made on different days. One sample of each cheese formulation was frozen at $-20{ }^{\circ} \mathrm{C}$ $\pm 2{ }^{\circ} \mathrm{C}$ (Time 0 ) and other was refrigerated for 20 days at $4{ }^{\circ} \mathrm{C} \pm 2{ }^{\circ} \mathrm{C}$, and frozen on the $20^{\text {th }}$ day after production (Time 20) at $4{ }^{\circ} \mathrm{C} \pm 2{ }^{\circ} \mathrm{C}$. This aimed to control proteolysis in the cheeses and improve the reliability of the results, because significant proteolysis can occur after 20 days of refrigerated storage.

\section{Collection of commercial buffalo mozzarella}

Samples of commercially available buffalo mozzarella were collected in retail stores in different locations of Bahia, Brazil. A total of 6 commercial brands were collected, with 3 different lots of each brand (each lot corresponding to a replicate), with 3 replicates each totaling 18 different samples. For better standardization and control of proteolysis, all cheeses were acquired after a maximum period of 20 days after the date of production, and frozen at $-20{ }^{\circ} \mathrm{C} \pm 2{ }^{\circ} \mathrm{C}$ on the $20^{\text {th }}$ day after production (Time 20).

\section{Chemical composition and physicochemical} characterization

The ash content, moisture, fat in dry extract (FDE), protein, total dry extract (TDE), defatted dry extract (DDE) and titratable acidity were determined for each cheese. All measurements were made in triplicate, following the methodology described by the Adolfo Lutz Institute (IAL, 2008).

\section{Extraction of the water-soluble peptides (WSP)}

WSP were extracted from RTB and RTC cheeses, as well as the samples of commercial buffalo mozzarella, was performed according to Ong et al. (2007), with adaptations. In brief, $10 \mathrm{~g}$ of the crushed sample was homogenized (Q226K, Quimis, Diadema, SP, Brazil) in $50 \mathrm{~mL}$ of ultrapure water (Milli-Q, Millipore Corp., Bedford, MA, USA) in a shaker at $200 \mathrm{rpm}$ for 60 minutes. The homogenate was filtered, and then centrifuged (Sorvall, Newtown, CT, USA) for consecutive 20 minute intervals at $4{ }^{\circ} \mathrm{C} \pm 1{ }^{\circ} \mathrm{C}$ and $4000 \times g$. Between centrifugations, the supernatant was filtered with quantitative filter paper (Whatman no. 41). The extracts containing the WSP were frozen at $-80{ }^{\circ} \mathrm{C} \pm 2{ }^{\circ} \mathrm{C}$ for 24 hours and freeze-dried at -48 ${ }^{\circ} \mathrm{C} \pm 2{ }^{\circ} \mathrm{C}$ and $0.040 \mathrm{mBar}$ for 72 hours in a bench freezer (FreeZone 4.5 L, Labconco, Kansas City, MO, USA). After freeze drying, the WSP extracts were stored at $-20^{\circ} \mathrm{C} \pm 2{ }^{\circ} \mathrm{C}$ for later electrophoretic analysis. 


\section{$S D S-P A G E$}

Polyacrylamide gels were used for the assessment of the electrophoretic profile of the total extracted protein and WSP of the cheeses. Polyacrylamide stacking gels were made with $4.9 \%$ (w/v) polyacrylamide (Sigma, St. Louis, MO, USA) in $0.125 \mathrm{Mol} \cdot \mathrm{L}^{-1}$ Tris- $\mathrm{HCl}$ (Vetec, Duque de Caxias, RJ, Brazil) buffer, $\mathrm{pH}$ 6.8, and separating gels were made with $15.4 \%(\mathrm{w} / \mathrm{v})$ polyacrylamide in 0.38 $\mathrm{Mol} \cdot \mathrm{L}^{-1}$ of Tris- $\mathrm{HCl}$ buffer, $\mathrm{pH} 8.8$, containing $0.1 \%(\mathrm{w} / \mathrm{v})$ SDS (Cromoline, Diadema, SP, Brazil) (LAEMMLI, 1970).

The freeze-dried WSP extracts were dissolved in $0.125 \mathrm{Mol} \cdot \mathrm{L}^{-1}$ of Tris- $\mathrm{HCl}$ buffer, $\mathrm{pH} 6.8$, to obtain a concentration of $2 \mathrm{mg} \cdot \mathrm{mL}^{-1}$. Subsequently, $0.1 \%$ $(\mathrm{w} / \mathrm{v})$ of SDS and $5 \%(\mathrm{v} / \mathrm{v})$ of $\beta$-mercaptoethanol (Sigma, St. Louis, MO, USA) were added and the peptides were homogenized for 3 minutes. A $20 \mu \mathrm{L}$ aliquot of each sample was then loaded onto each gel, and separated electrophoretically at $4{ }^{\circ} \mathrm{C} \pm 2{ }^{\circ} \mathrm{C}$ for 90 minutes at $250 \mathrm{~V}, 30 \mathrm{~mA}$, and $15 \mathrm{~W}$ (Apelex PS 304 Minipac II, France). The molecular mass standards (Bio-Rad, Hercules, CA, USA) were miosin $(200.0 \mathrm{kDa}), \beta$-galactosidase $(116.2 \mathrm{kDa})$, phosphorylase b $(97.4 \mathrm{kDa})$, bovine serum albumin $(66.2 \mathrm{kDa})$, ovalbumin $(45.0 \mathrm{kDa})$, carbonic anhydrase $(31.0 \mathrm{kDa})$, trypsin inhibitor $(21.5 \mathrm{kDa})$, lysozyme $(14.5 \mathrm{kDa})$ and aprotinin $(6.5 \mathrm{kDa})$.

After migration, the proteins were fixed with $12 \%(\mathrm{~m} / \mathrm{v})$ trichloroacetic acid (TCA) (Sigma, St. Louis, MO, USA) for 30 minutes, and then stained with Coomassie Blue G250 (Vetec, Duque de Caxias, RJ, Brazil), dissolved in a mixture of $50 \%$ (v/v) ethanol (Vetec, Duque de Caxias, RJ, Brazil) and $12 \%(\mathrm{w} / \mathrm{v})$ of TCA, for 2 hours. Gels were then destained in 30\% (v/v) ethanol and 7.5\% (v/v) of acetic acid (Vetec, Duque de Caxias, RJ, Brazil). The protein gels were scanned and later, along with the peptides gels, stained with silver nitrate, according to the adapted protocol of Bloom et al. (1987). The gels were stored in a solution of acetic acid $1 \%(\mathrm{v} / \mathrm{v})$ before scanning.

\section{Statistical analysis}

The present study made use of a completely randomized design (CRD) for the comparisons made. The time of refrigeration (Time 0 and Time 20) was compared using univariate analysis of variance (ANOVA), with the F statistic at 5\% $(\alpha=$ $0.05)$. Within refrigeration time groups, the cheese formulation was compared by regression analysis at $5 \%$ significance. The mathematical models were chosen according to the significant effects of the model $(p \leq 0.05)$, lack of fit $(p>0.05)$ and coefficients of determination $\left(\mathrm{R}^{2}\right)$ in relation to the $\mathrm{SQ}_{\mathrm{TRAT}}$ that were capable of explaining the total variation through adjusted regression.

For the commercially available mozzarella samples, the experimental design was completely randomized, and means were compared by ANOVA, with a Tukey post-hoc test at 5\% probability ( $\alpha=$ $0.05)$. All the above statistical procedures were executed using the statistical program SAEG (RIBEIRO JUNIOR, 2001).

\section{Results and Discussion}

For all measured variables, refrigeration time did not result in any significant statistical difference at $5 \%$ probability $(\mathrm{p}>0.05)($ Table 1$)$.

During the refrigeration time, the proteolysis and storage effects that the cheeses experienced that may be associated with the additions of cow's milk, have not apparently altered the chemical composition or physicochemical characteristics assessed. 
Table 1. Average values + standard deviation of chemical composition (moisture, ashes, FDE, protein, TDE, DDE) and physicochemical characterization (titratable acidity) of the mozzarella cheeses at times 0 and 20.

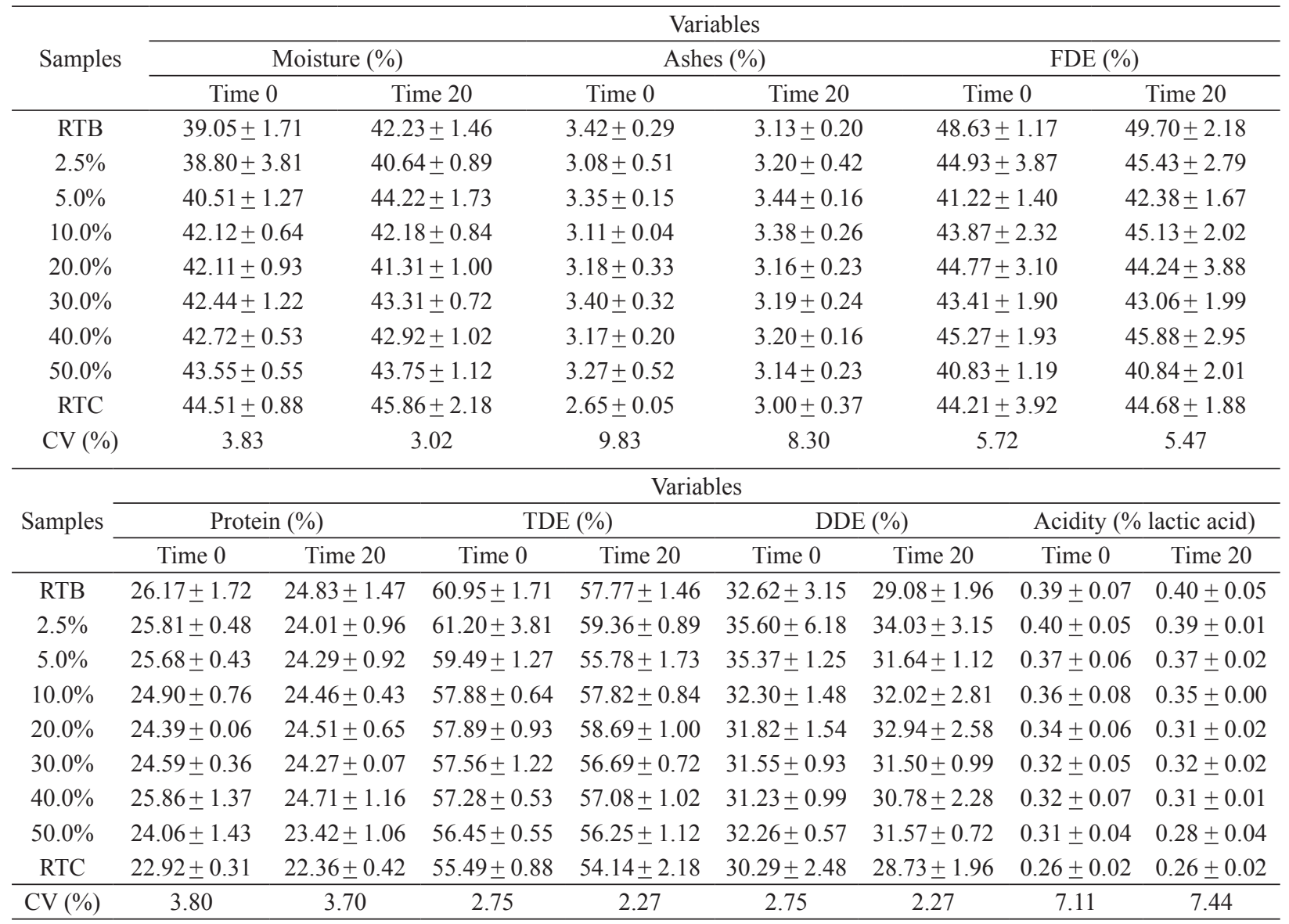

The samples are presented in increasing proportion of cow's milk. RTB $=$ sample with $100 \%$ buffalo's milk. RTC $=$ sample with $100 \%$ cow's milk. FDE $=$ fat in dry extract. TDE $=$ total dry extract. DDE $=$ defatted dry extract. The acidity is expressed in $\%$ of lactic acid. $\mathrm{CV}=$ coefficient of variation.

It was not possible to fit a linear or quadratic equation $(\mathrm{p}>0.05)$ to the ash content, FDE, or protein at Time 0 . After 20 days of refrigerated storage, the equations were not adjusted for moisture, ash content, FDE, protein, TDE and DDE, indicating that there were no statistically significant differences between the samples (Table 2).

From the adjusted regression equations, we could deduce that the RTB had the lowest moisture content and the highest protein TDE, DDE and acidity at time 0 . After 20 days, cheeses with higher content of buffalo milk had higher acidity.

There was no statistically significant difference $(p>0.05)$ between the moisture, TDE and DDE in the commercial buffalo mozzarella samples. However, there was a statistically significant difference $(\mathrm{p} \leq 0.05)$ between the ash, FDE, protein, and acidity (Table 3 ). 
Table 2. Regression equations adjusted for chemical composition and physicochemical characterization of the cheeses at 0 and 20 days of refrigeration.

\begin{tabular}{|c|c|c|c|c|}
\hline \multirow{2}{*}{ Variables } & \multicolumn{2}{|l|}{ Time 0} & \multicolumn{2}{|c|}{ Time 20} \\
\hline & Estimeted equations & $\mathrm{R}^{2}$ & Estimeted equations & $\mathrm{R}^{2}$ \\
\hline Moisture (\%) & $\hat{Y}=0.6802 X+38.3555$ & 0.9239 & $* * *$ & $* * *$ \\
\hline Ashes $(\%)$ & $* * *$ & $* * *$ & $* * *$ & $* * *$ \\
\hline FDE $(\%)$ & $* * *$ & $* * *$ & $* * *$ & $* * *$ \\
\hline Protein $(\%)$ & *** & $* * *$ & $* * *$ & $* * *$ \\
\hline TDE $(\%)$ & $\hat{Y}=-0.6802 X+61.6445$ & 0.9239 & $* * *$ & $* * *$ \\
\hline DDE $(\%)$ & $\hat{Y}=-0.6802 X+61.6445$ & 0.9239 & $* * *$ & $* * *$ \\
\hline Acidity & $\hat{\mathrm{Y}}=-1.5520 \mathrm{X}+41.7888$ & 0.9297 & $\hat{\mathrm{Y}}=-1.7363 \mathrm{X}+41.9135$ & 0.9659 \\
\hline
\end{tabular}

${ }^{*} \mathrm{FDE}=$ fat in dry extract. TDE $=$ Total dry extract. $\mathrm{DDE}=$ Defatted dry extract. The acidity was expressed in $\%$ of lactic acid. $\mathrm{Y}=$ answer variable. $\mathrm{X}=$ levels of treatments (formulations). $\mathrm{R}^{2}=$ coefficient of determination calculated in relation to the $\mathrm{SQ}_{\mathrm{TRAT}}{ }^{* * *}$ (it was not possible to adjust regression equation).

Table 3. Average values \pm standard deviation of the chemical composition and physicochemical characterization of commercial brands of buffalo mozzarella following 20 days of refrigeration.

\begin{tabular}{cccccccc}
\hline Samples & $\begin{array}{c}\text { Moristure } \\
(\%)\end{array}$ & $\begin{array}{c}\text { Ashes } \\
(\%)\end{array}$ & $\begin{array}{c}\text { FDE } \\
(\%)\end{array}$ & $\begin{array}{c}\text { Protein } \\
(\%)\end{array}$ & $\begin{array}{c}\text { TDE } \\
(\%)\end{array}$ & $\begin{array}{c}\text { DDE } \\
(\%)\end{array}$ & $\begin{array}{c}\text { Acidity } \\
(\%) \text { lactic acid }\end{array}$ \\
\hline $\mathrm{A}$ & $43.42 \pm 2.08 \mathrm{a}$ & $3.56 \pm 0.09 \mathrm{a}$ & $53.99 \pm 5.43 \mathrm{ab}$ & $20.88 \pm 1.13 \mathrm{ab}$ & $56.58 \pm 2.08 \mathrm{a}$ & $26.06 \pm 3.54 \mathrm{a}$ & $0.30 \pm 0.04 \mathrm{ab}$ \\
$\mathrm{B}$ & $43.10 \pm 2.35 \mathrm{a}$ & $2.33 \pm 0.12 \mathrm{~b}$ & $53.90 \pm 0.75 \mathrm{ab}$ & $20.29 \pm 1.47 \mathrm{ab}$ & $56.90 \pm 2.35 \mathrm{a}$ & $26.23 \pm 1.05 \mathrm{a}$ & $0.28 \pm 0.00 \mathrm{ab}$ \\
$\mathrm{C}$ & $40.70 \pm 1.21 \mathrm{a}$ & $2.32 \pm 0.05 \mathrm{~b}$ & $56.97 \pm 2.30 \mathrm{a}$ & $19.60 \pm 0.29 \mathrm{~b}$ & $59.30 \pm 1.21 \mathrm{a}$ & $25.54 \pm 1.89 \mathrm{a}$ & $0.35 \pm 0.05 \mathrm{a}$ \\
$\mathrm{D}$ & $41.84 \pm 1.07 \mathrm{a}$ & $3.23 \pm 0.03 \mathrm{a}$ & $54.36 \pm 0.31 \mathrm{ab}$ & $19.87 \pm 0.74 \mathrm{~b}$ & $58.16 \pm 1.07 \mathrm{a}$ & $26.54 \pm 0.31 \mathrm{a}$ & $0.29 \pm 0.05 \mathrm{ab}$ \\
$\mathrm{E}$ & $42.69 \pm 1.77 \mathrm{a}$ & $3.23 \pm 0.26 \mathrm{a}$ & $46.46 \pm 2.59 \mathrm{~b}$ & $22.65 \pm 1.21 \mathrm{a}$ & $57.31 \pm 1.77 \mathrm{a}$ & $30.68 \pm 1.42 \mathrm{a}$ & $0.24 \pm 0.02 \mathrm{~b}$ \\
$\mathrm{~F}$ & $43.29 \pm 1.42 \mathrm{a}$ & $3.51 \pm 0.39 \mathrm{a}$ & $51.43 \pm 3.11 \mathrm{ab}$ & $18.67 \pm 0.63 \mathrm{~b}$ & $56.71 \pm 1.42 \mathrm{a}$ & $27.57 \pm 2.38 \mathrm{a}$ & $0.31 \pm 0.06 \mathrm{ab}$ \\
\hline $\mathrm{CV}(\%)$ & 4.02 & 6.73 & 5.55 & 4.89 & 2.97 & 7.52 & 12.78 \\
\hline
\end{tabular}

*Average values followed by the same letter in the columns do not differ statistically according to Tukey test, at 5\% level of probability $(\alpha=0.05)$. The samples A, B, C, D, E and F correspond to the commercial brands of buffalo's mozzarella. FDE $=$ Fat in dry extract. $\mathrm{TDE}=$ Total dry extract. $\mathrm{DDE}=$ Defatted dry extract. $\mathrm{CV}=$ coefficient of variation.

The moisture of all the samples varied between $40.70 \%$ and $43.42 \%$ (Table 3 ), therefore designating the cheeses as 'medium moisture' or 'semi-hard' consistency (BRASIL, 1996), which is less than the maximum of $60 \%$ recommended by mozzarella cheese legislation (BRASIL, 1997).

The FDE ranged from $46.46 \%$ to $56.97 \%$, with all the samples with values above $35 \%$, which is the minimum value set by legislation (BRASIL, 1997), considered as high fat cheeses (BRASIL, 1996).

There is no reference data available in the legislation for the other measured variables (ashes, protein, TDE, DDE and acidity), although some previous studies could be used to compare results. El Owni e Osman (2009) reported 2.38\% ash content in buffalo mozzarella; however, Sameen et al. (2008) reported an ash content of $4.11 \%$. Ahmad et al. (2008) observed that buffalo mozzarella has a higher protein content than cow's mozzarella. This may explain the higher acidity, because the proteins are also measured in the titratable acidity test, increasing the perceived acidity of the samples.

The protein content varied between $18.67 \%$ and $22.65 \%$. However, it was not possible to ascertain the authenticity of the commercial brands through this variable, because the species of origin cannot be distinguished by total protein content, but rather by the sub-products obtained from proteolysis, which can be identified by more detailed techniques.

SDS-PAGE was employed to compare the electrophoretic profiles of proteins and peptides derived from mozzarella cheeses made from buffalo or cow milk, or mixtures of those. 
At time 0 (Figure 1 (a) and (b)) small differences were observed between sample 1 (RTB) and 9 (RTC), especially in the $\alpha_{\mathrm{s}}$-CN structure, as well as differences in the electrophoretic mobility of the $\beta-\mathrm{CN}$. With increasing percentage of cow's milk, slight changes in the structure and mobility of the $\alpha_{\mathrm{s}}-\mathrm{CN}$ and $\beta-\mathrm{CN}$ were observed.

Following refrigeration for 20 days, more peptides were observed in the cheese, with degradation of the fractions $\alpha_{\mathrm{s}}-\mathrm{CN}$ e $\beta-\mathrm{CN}$, especially in the regions below $\beta-\mathrm{CN}$ in the RTB sample (RTB) (Figure 1 (d)). The appearance of bands in this region after 20 days of storage is probably as a result of proteolytic activity, and the presence of a small band below the $\beta$-CN was observed in the RTC, at time 0 (samples 9) (Figure 1 (b)), but after 20 days this band had faded and is more intense in the RTB sample (Figure 1 (c) and (d)).

Both Coomassie and silver staining gave the same results in the present study. The assessed samples underwent changes in the $\alpha_{\mathrm{s}}-\mathrm{CN}$ with increasing proportion of cow's milk. Below the region of the para- $\kappa-\mathrm{CN}$ we observed $\gamma_{2}-\mathrm{CN}$ and $\gamma_{3}-\mathrm{CN}$ (Figure 1 (b) and (d)), which were formed by the action of the coagulant agent in the cheese production (rennet), which hydrolyzes $\kappa-\mathrm{CN}$, exposing the $\beta-\mathrm{CN}$. The plasmin can then act on the protein, forming these peptides (Figure 1 (b) and (d)). According to Sgarbieri (2005), the $\beta-\mathrm{CN}$ structure is susceptible to hydrolysis by the protease plasmin, a proteolytic enzyme of endogenous origin, producing peptide fragments referred as $\gamma-\mathrm{CN}$, that remain in the casein micelles. Other small structures are also formed due to the action of the plasmin, but they diffuse into the liquid phase (sorum) during cheese production. Although there are differences in the protein composition of the cheeses produced with milk from cow and buffalo (RTB and RTC) (Table 1), it was not possible to differentiate these cheeses based on electrophoretic analysis of the differences in the formation of $\gamma_{2}-\mathrm{CN} \mathrm{e} \gamma_{3}-\mathrm{CN}$, which means that the higher protein percentage of the buffalo milk did not cause more formation of $\gamma_{2}-\mathrm{CN}$ and $\gamma_{3}-\mathrm{CN}$ by the action of plasmin.
Six commercial brands of mozzarella were analyzed and their characteristics were compared with those of RTB and RTC (Figure 2 (a) and (b)).

Sample F was similar to RTC, especially in the bands corresponding to $\alpha_{\mathrm{s}}-\mathrm{CN}$ and $\beta-\mathrm{CN}$ (Figure 2 (a) and (b)), and we therefore suspect that that sample contained cow's milk. The other brands were more similar to RTB, and we therefore have no evidence of the addition of cow's milk to these cheeses. In particular, the structure and mobility of the $\alpha_{\mathrm{s}}-\mathrm{CN}, \beta-\mathrm{CN}$ and para- $\kappa-\mathrm{CN}$ were similar to those of the RTB.

Although cheeses made of cow and buffalo milk contains peptides with similar characteristics, it was possible to observe the differences between them, especially regarding the structure and mobility, following electrophoresis (Figure 3).

The commercial samples had similarities with peptides that are specific to cow's milk were (Figure 3 ). We therefore conclude that it is possible that cow's milk was added during production, which is not legal given that the packaging only mentions the use of buffalo milk.

Peptides isolated from samples F (Figure 3 (a)), $\mathrm{C}$, and F (Figure 3 (b)) were similar to peptides in the region of $21 \mathrm{kDa}$ and $16 \mathrm{kDa}$ of the cow milk reference cheese. In the other samples, cow's milk marker peptides were not detected, and instead the peptides were similar to the reference cheese made from buffalo milk.

SDS-PAGE analysis of the peptides is more efficient than the analysis of the protein fractions, but both can be used simultaneously to differentiate between cow and buffalo milk cheese. There was evidence of the addition of cow's milk in 5 of the 18 samples analyzed, indicating that this is still a usual practice in Brazil. Other proteomic techniques (electrophoretic, chromatographic and immunological) are necessary (HINZ et al., 2012) because they can both identify and quantify the animal origins of the cheese product (VELOSO et al., 2004; MAYER, 2005). 
Figure 1. Electrophoretic profile (SDS-PAGE) of mozzarella cheeses, (a) stained with Coomassie blue (time 0), (b) stained with silver nitrate (time 0), (c) stained with Coomassie blue (time 20), (d) stained with silver nitrate (time 20). (M) Molecular mass marker (kDa); (1) RTB; (2) mozzarella with 2.5\% of cow's milk in buffalo's milk; (3) 5.0\%; (4) $10.0 \%$; (5) $20.0 \%$; (6) 30.0\%; (7) 40.0\%; (8) 50.0\%; (9) RTC. $\alpha_{\mathrm{s}}-\mathrm{CN}=\alpha_{\mathrm{s}}$-casein; $\beta$-CN $=\beta$-casein; $\kappa$-CN $=\kappa$-casein;

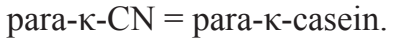

(a)

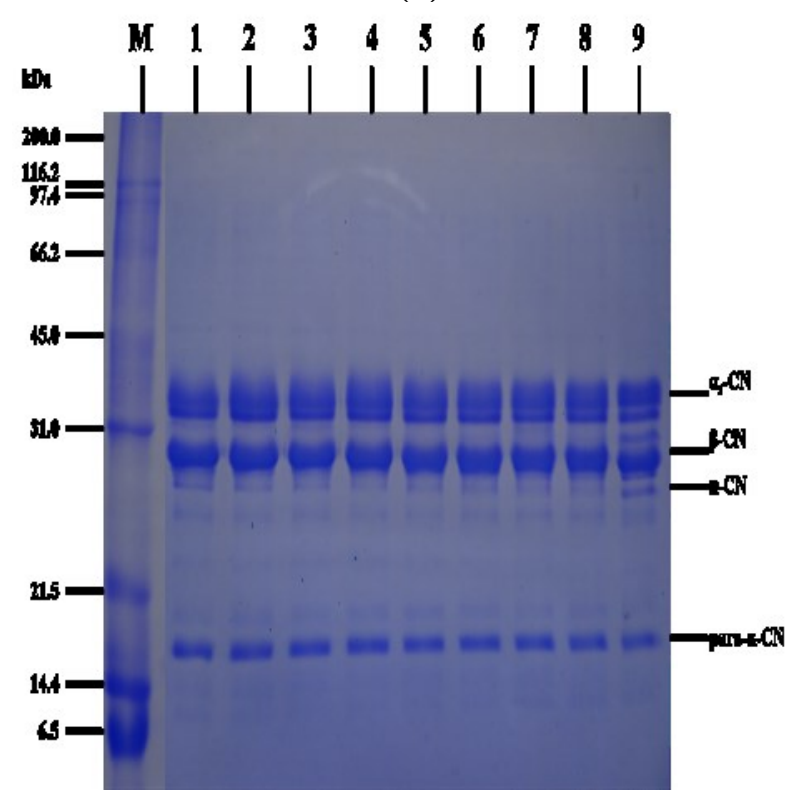

(c)

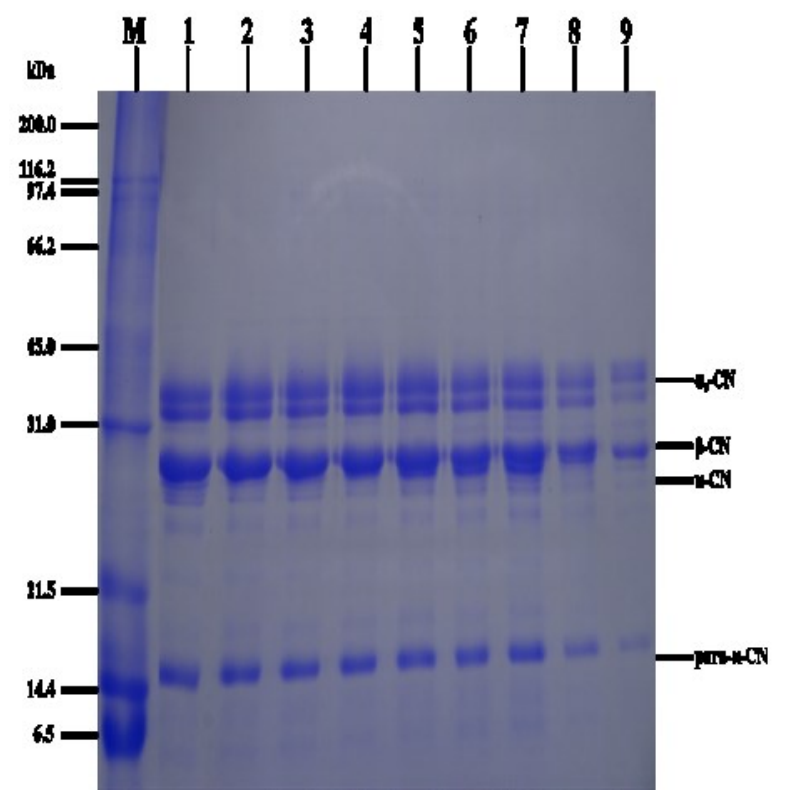

(b)

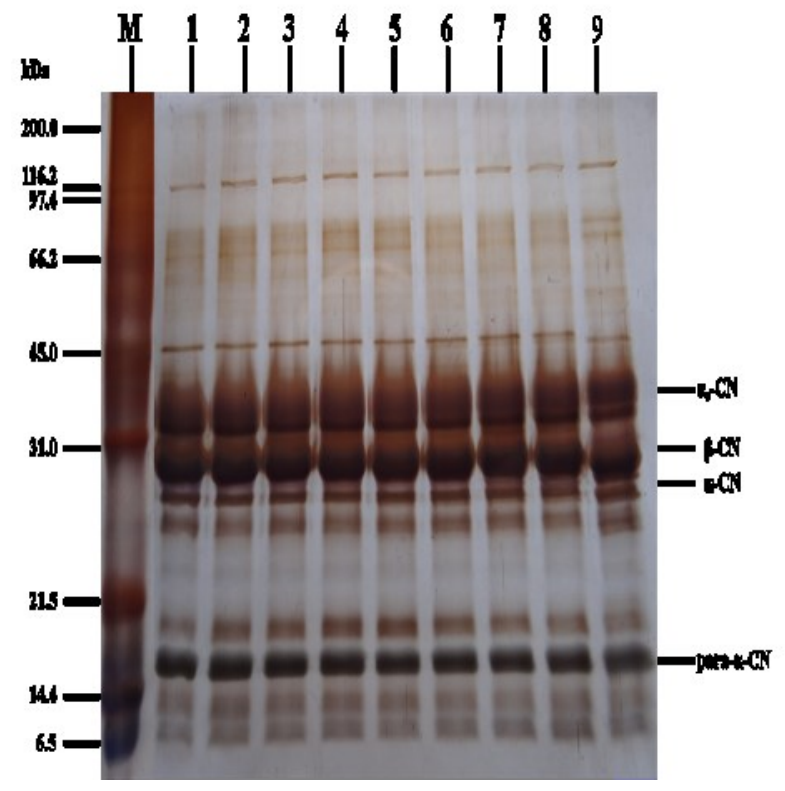

(d)

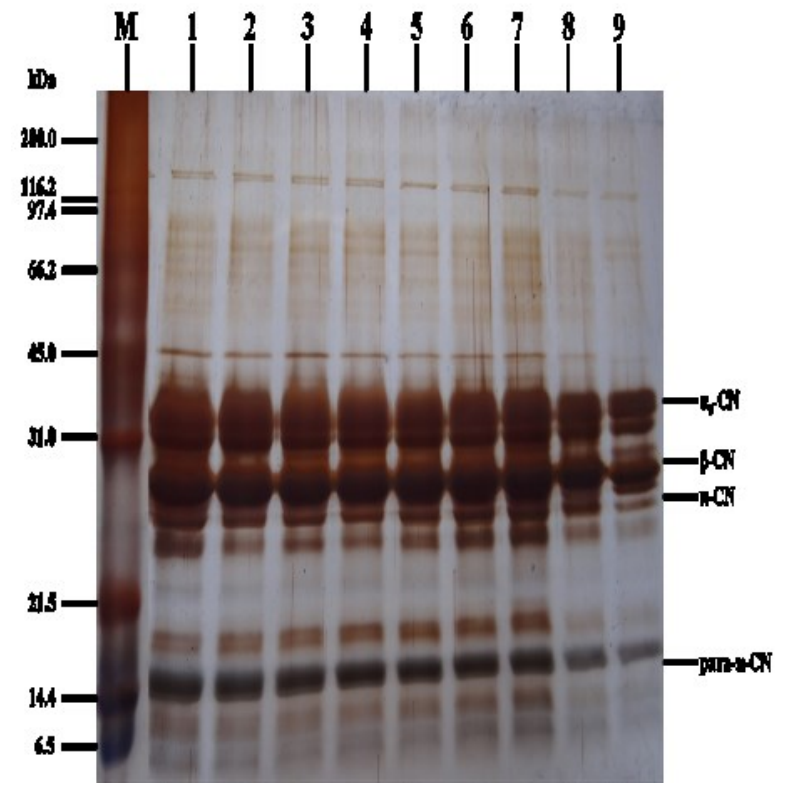


Figure 2. Electrophoretic profile (SDS-PAGE) of commercial samples of buffalo mozzarella, (a) stained with Coomassie blue ( $1^{\text {st }}$ replicate), (b) stained with silver nitrate ( $1^{\text {st }}$ replicate). (M) Molecular mass marker $(\mathrm{kDa}) ;(1)$ RTB; A, B, C, D, E and F correspond to the commercial brands; (2) RTC; $\alpha_{\mathrm{s}}-\mathrm{CN}=\alpha_{\mathrm{s}}$-casein; $\beta$-CN $=\beta$-casein; $\kappa$-CN $=\kappa$-casein; para- $\kappa-\mathrm{CN}=$ para- $\kappa$-casein.

(a)

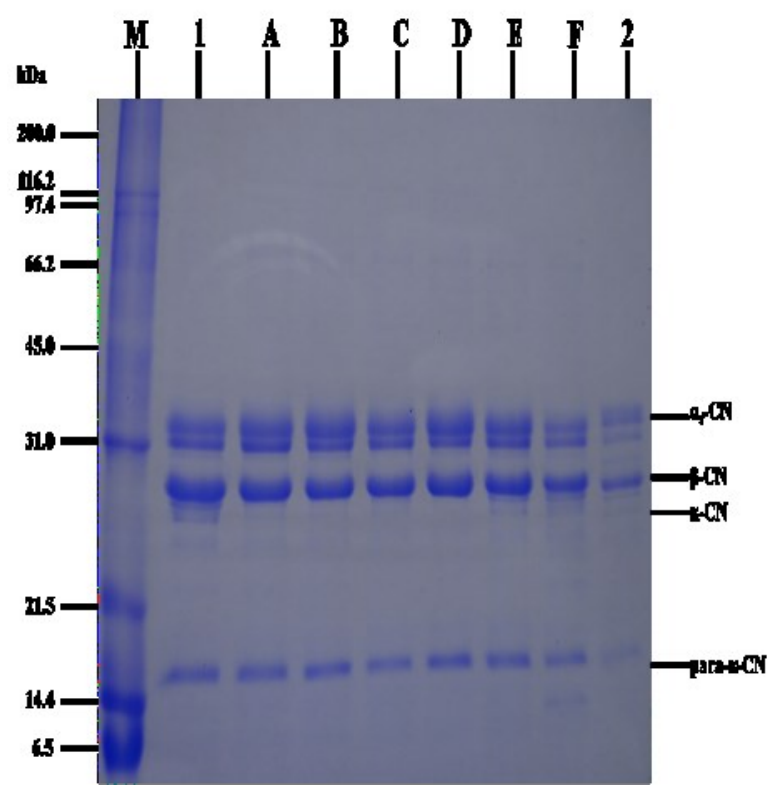

(b)

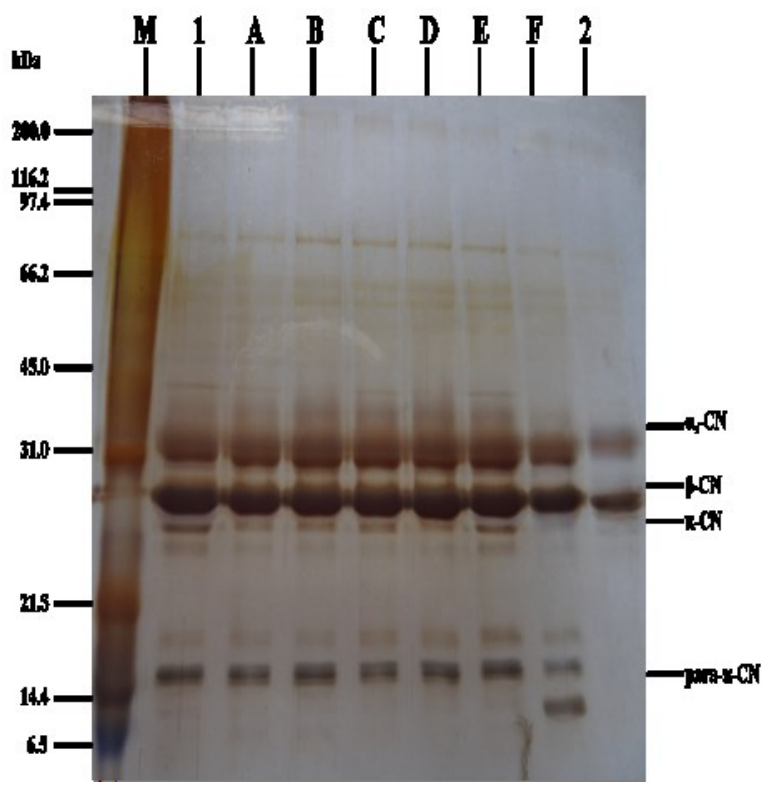

Figure 3. Electrophoretic profile (SDS-PAGE) of water-soluble peptides (WSP) extracted from the commercial samples of buffalo's mozzarella, (a) stained with silver nitrate ( $1^{\text {st }}$ replicate), (b) stained with silver nitrate ( $3^{\text {rd }}$ replicate). (M) Molecular mass marker (kDa); (1) RTB; A, B, C, D, E and F correspond to the commercial brands analyzed; (2) RTC.

(a)

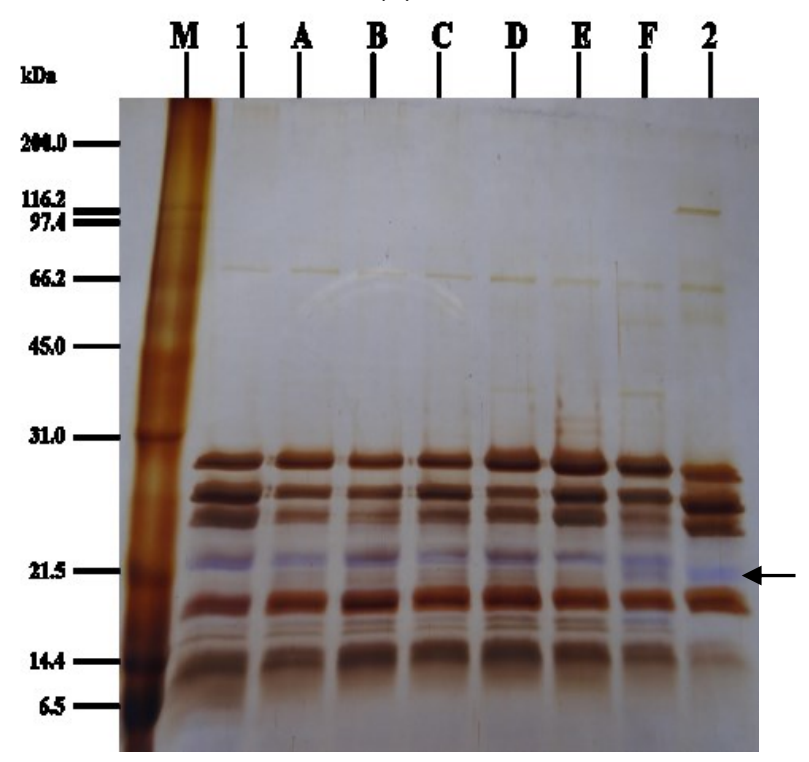

(b)

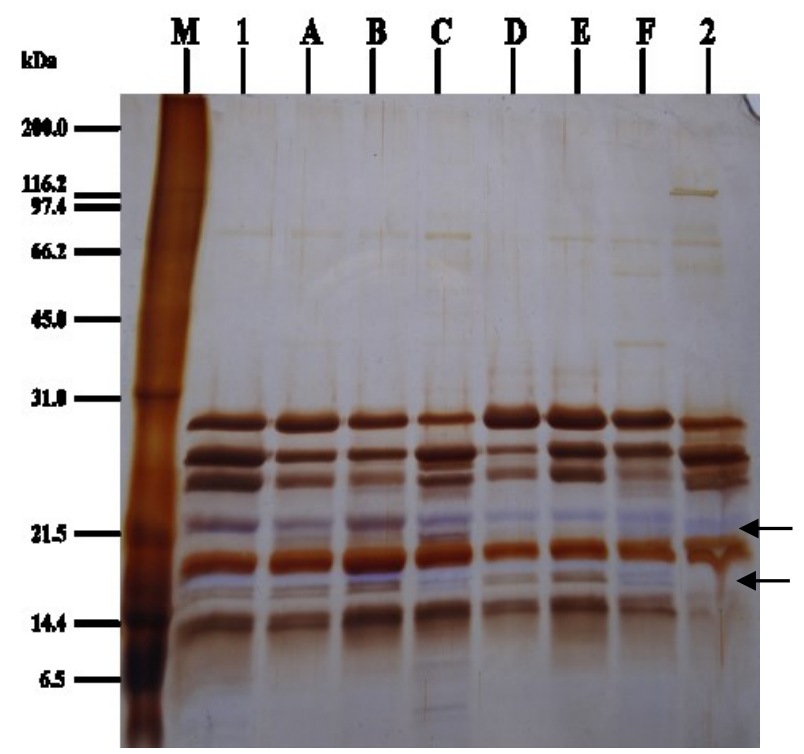




\section{Conclusions}

It was not possible to detect the addition of cow's milk in buffalo mozzarella using the chemical composition and physicochemical characteristics studied alone. All the evaluated commercial brands had satisfactory results for the moisture content and FDE, which are set by legislation.

SDS-PAGE was successfully used to separate proteins and peptides of bovine and buffalo origin. Five of the eighteen commercial samples of buffalo mozzarella assessed had evidence of the addition of cow's milk.

\section{Acknowledgments}

The authors are grateful to the "Comissão de Aperfeiçoamento de Pessoal do Nível Superior (CAPES)" for providing scholarships.

\section{References}

AHMAD, S.; GAUCHER, I.; ROUSSEAU, F.; BEAUCHER, E.; PIOT, M.; GRONGNET, J. F.; GAUCHERON, F. Effects of acidification on physicochemical characteristics of buffalo milk: a comparison with cow's milk. Food Chemistry, Reading, v. 106, n. 1, p. 11-17, jan. 2008 .

BLOOM, H.; BEIER, H.; GROSS, H. J. Improved silver staining of plant protein, RNA and DNA in polyacrylamide gels. Electrophoresis, Stillwater, v. 8, n. 2, p. 93-99, 1987.

BRASIL. Regulamento técnico de identidade e qualidade de queijos. Diário Oficial [da] União, Brasília, 1996. Seção 1, p. 1-6.

Regulamento técnico para fixação de identidade e qualidade do queijo Mozzarella (Muzzarella ou Mussarela). Diário Oficial [da] União, Brasília, 1997. Seção 1, p. 1-4.

CZERWENKA，C.; MÜLLER, L.; LINDNER, W. Detection of the adulteration of water buffalo milk and mozzarella with cow's milk by liquid chromatographymass spectrometry analysis of $\beta$-lactoglobulin variants. Food Chemistry, Reading, v. 122, n. 1, p. 901-908, oct. 2010.
EGITO, A. S.; ROSINHA, G. M. S.; LAGUNA, L. E.; MICLO, L.; GIRARDET, J. M.; GAILLARD, J. L. Método eletroforético rápido para detecção da adulteração do leite caprino com leite bovino. Arquivo Brasileiro de Medicina Veterinária e Zootecnia, Belo Horizonte, v. 58, n. 5, p. 932-939, may 2006.

EL OWNI, O. A. O.; OSMAN, S. E. Evaluation of chemical composition and yield of mozzarella cheese using two different methods of processing. Pakistan Journal of Nutrition, Faisalabad, v. 8, n. 5, p. 684-687, 2009.

ENNE, G.; ELEZ, D.; FONDRINI, F.; BONIZZI, I.; FELIGINI, M.; ALEANDRI, R. High-performance liquid chromatography of governing liquid to detect illegal bovine milk's addition in water buffalo Mozzarella: Comparison with results from raw milk and cheese matrix. Journal of Chromatography A, Gangtok, v. 1094, n. 1-2, p. 169-174, sept. 2005.

FELIGINI, M.; BONIZZI, I.; CURIK, V. C.; PARMA, P.; GREPPI, G. F.; ENNE, G. Detection of adulteration in Italian mozzarella cheese using mitochondrial DNA templates as biomarkers. Food Technology and Biotechnology, Zagreb, v. 43, n. 1, p. 91-95, feb. 2005.

GUERREIRO, J. S.; BARROS, M.; FERNANDES, P.; PIRES, P.; BARDSLEY, R. Principal component analysis of proteolytic profiles as markers of authenticity of PDO cheeses. Food Chemistry, Reading, v. 136, n. 3-4, p. 1526-1532, feb. 2013.

HINZ, K.; O'CONNOR, P. M.; HUPPERTZ, T.; ROSS, R. P.; KELLY, A. L. Comparison of the principal proteins in bovine, caprine, buffalo, equine and camel milk. Journal of Dairy Research, Cambridge, v. 79, n. 2, p. 185-191, feb. 2012.

INSTITUTO ADOLFO LUTZ - IAL. Métodos físicoquímicos para análise de alimentos. 4. ed. Brasília: Ministério da Saúde, 2008. 1000 p.

LAEMMLI, U. K. Clevage of structural proteins during the assembly of head of bacteriophage T4. Nature, London, v. 227, n. 1, p. 680-685, aug. 1970.

LOPPARELLI, R. M.; CARDAZZO, B.; BALZAN, S.; GIACCONE, V.; NOVELLI, E. Real-time taqman polymerase chain reaction detection and quantification of cow DNA in pure water buffalo mozzarella cheese: Method validation and its application on comercial samples. Journal of Agricultural and Food Chemistry, Reading, v. 55, n. 9, p. 3429-3434, may 2007. 
LÓPEZ-CALLEJA, I.; ALONSO, G.; FAJARDO, V.; RODRÍGUEZ, P. E.; HERNÁNDEZ, P. E.; GARCÍA, T.; MARTÍN, R. PCR detection of cow's milk in water buffalo milk and mozzarella cheese. International Dairy Journal, Edmonton, v. 15, n. 11, p. 1122-1129, nov. 2005.

MAYER, H. K. Milk species identification in cheese varieties using electrophoretic, chromatographic and PCR techniques. International Dairy Journal, Ede, v. 15, n. 6-9, p. 595-604, mar. 2005.

ONG, L.; HENRIKSSON, A.; SHAH, N. P. Angiotensin converting enzyme-inhibitory activity in Cheddar cheeses made with the addition of probiotic Lactobacillus casei sp.. Le Lait, Rennes, v. 87, n. 2, p. 149-165, jan. 2007.

RIBEIRO JUNIOR, J. J. Análises estatísticas no SAEG. Viçosa, MG: Editora UFV, 2001. 301 p.

RUSSO, R.; SEVERINO, V.; MENDEZ, A.; LLIBERIA, J.; PARENTE, A.; CHAMBERY, A. Detection of buffalo mozzarella adulteration by an ultra-high performance liquid chromatography tandem mass spectrometry methodology. Journal of Mass Spectrometry, Nashville, v. 47, n. 11, p. 1407-1414, nov. 2012.

SAMEEN, A.; ANJUM, F. M.; HUMA, N.; NAWAZ, H. Quality evaluation of mozzarella cheese from different milk sources. Pakistan Journal of Nutrition, Faisalabad, v. 7, n. 6, p. 753-756, june 2008.

SGARBIERI, V. C. Revisão: propriedades estruturais e físico-químicas das proteínas do leite. Brazilian Journal of Food Technology, Campinas, v. 8, n. 1, p. 43-56, jan./ mar. 2005.

VELOSO, A. C. A.; TEIXEIRA, N.; PERES, A. M.; MENDONÇA, A.; FERREIRA, I. M. P. L. V. O. Evaluation of cheese authenticity and proteolysis by HPLC and urea-polyacrylamide gel electrophoresis. Food Chemistry, Reading, v. 87, n. 2, p. 289-295, mar. 2004. 
